Marquette University

e-Publications@Marquette

$1-1-2012$

\title{
Aging, Retirement and Human Resources Management: A Strategic Approach
}

Barbara L. Rau

University of Wisconsin - Oshkosh

Gary A. Adams

Marquette University, gary.adams@marquette.edu

Published version. "Aging, Retirement and Human Resources Management: A Strategic Approach," in The Oxford Handbook of Retirement. Ed. Mo Wang. Oxford; New York: Oxford University Press, 2012: 117-135. DOI. (C) 2012 Oxford University Press. Used with permission. 


\title{
CHAPTER
}

\section{Aging, Retirement, and Human \\ Resources Management: A Strategic Approach}

Barbara L. Rau and Gary A. Adams

\begin{abstract}
This chapter introduces the organizational view of retirement by exploring the relationship between organizational strategy and human resource management decisions regarding retirement. The authors begin with an overview of organizational strategy and discuss two methods used to plan for an aging and retiring workforce. Several key human resource decisions related to retirement are then addressed. In the pre-retirement phase, the role of HR in helping employees to prepare for retirement is discussed, focusing primarily on financial planning and other retirement-related benefits. Next, human resource decisions pertaining to managing a retirement-ready workforce are discussed, addressing specifically the issues of knowledge transfer and motivating performance. Finally, interactions with individuals after retirement are discussed by looking at recruitment and bridge employment.
\end{abstract}

Key Words: aging workforce, human resources strategy, organizational strategy, retirement, strategic human resources management, bridge employment, retirement benefits, succession planning, retirement planning, recruitment, knowledge management

With an aging workforce and increased financial incentives to continue working into one's later years, management of an older workforce and issues surrounding retirement have become increasingly important responsibilities for organizations. Many organizations anticipate that $35 \%-50 \%$ of their workforce will retire over the next five to seven years. For example, the Office of Personnel Management estimated that $45 \%$ of its full-time, permanent workforce would be cligible to retire in 2012 (OPM, 2008). The sheer number of retirements, and their subsequent effects on knowledge transfer, culture, innovation, and other key objectives, are forcing organizations to take a more strategic approach to managing the aging workforce. In fact, a national survey by researchers at Boston College found that $75 \%$ of employers had done at least some analysis of their workforce demographics in anticipation of the effects of retirement (Pitt-Catsouphes, Smyer, Matz-Costa, \& Kane, 2007).

In the broad sense, an organizational strategy is a plan to gain and retain a competitive advantage in the market (Schuler \& Jackson, 1987). For example, a company might focus on being the first to bring new products to the market or sell at the lowest cost. Human resource management practices that support an organization's overall business strategy are thought to play a critical role in sustaining a competitive advantage. This is because a firm's human resources are (1) rare and unique to the organization and (2) difficult to imitate. While a company may be able to copy another's production processes, logistics, or distribution practices, adopting similar HR practices does not guarantee the same results for the simple reason that each firm's human assets differ, and the impact of a given set of policies on any 
group of individuals is not necessarily the same, particularly when the circumstances or contexts differ.

Retirement can be seen both as a porentially disruptive source of turnover and an opportunity for change. Mass retirements, such as those experienced by companies offering early retirement incentives, can drain an organization of its knowledge and skills base, sometimes leaving less productive (and less desirable) employees. At the same rime, these retirements can free up an organization's resources and create opportunities for advancement within an organization. However, even a small number of retirements within a company can send ripple effects throughout the hierarchy, resulting in knowledge loss and straining the culture by disrupting former patrerns of work. Strategically managing retirement can help to ensure that the positive effects of retirement are realized while the negative effecrs are minimized. Further, it can help an organization understand how to time retirements, how to management retirement flow, and how to assess the impact of retirements on the organization as a whole.

From the organization's standpoint, retirement is a phenomenon that must be managed with a straregic perspective, preferably one that is consistent with that of the organization's overall business strategy. Simply put, a company that is looking to cut costs may be interested in encouraging retirement among its highly paid employees, while one that is looking to compete on the basis of quality may be unwilling to part prematurely with the greater knowledge and skills of its older workers. Similarly, a company looking to compete on the basis of innovative product design may benefit from a certain degree of churn or turnover among irs employees, while one focused on customer service quality may wish to reduce high turnover rates that interfere with establishing long-term customer relations.

Utilizing the concepts from strategic human resource management, this chapter will explore some key challenges organizations face in managing an aging, retiring, or retired workforce with an cyc toward supporting business strategy. We will begin the chapter with an overview of business strategy and implications of retirement for these strategies. We will discuss how organizations plan strategically for retirement through workforce management and succession planning. We will then discuss some key concerns organizations have in managing retirement issues for their pre-retirement workforce, including choice of retirement benefits, managing retirement benefits options, and encouraging employee retirement planning. Next, we discuss the implications of retirement for the current workforce and identify two key concerns of HR managers: knowledge transfer and motivating workers close to retirement. Finally, we discuss the interactions between organizations and retired individuals, including former employees. In particular, we discuss the advantages and challenges of retaining retirees and recruiting them back into the workforce

\section{Managing Retirement Strategically Strategic Management}

The application of human resource management to strategic management has focused on two schools of thoughr. First, it has been proposed that there is a set of "best practices" that any organization, regardless of its particular situation and context, can benefit from when applied to the management of its human resources. The best practices perspective finds evidence supporting the value of particular HR practices such as pay-for-performance, grievance processes, employce involvement programs, and performance management systems in improving firm profits (Becker \& Huselid, 1998; Becker \& Huselid, 1999; Huselid, 1995; Pfeffer, 1994). Alternatively, some researchers argue that HR practices must be designed to align with the particular firm strategy and environmental constraints faced by a particular organization (Wood, 1999; Boxall \& Purcell, 2008, Schuler \& Jackson, 1987).

It is generally accepted that both of these schools of thought have merit. In fact, researchers have begun to acknowledge that a firm's practices need to not only meet the strategy, but to do so in a way that meets the needs of different groups of employees (Lepak \& Snell, 2002; Tsui, Pearce, Porter, \& Tripoli, 1997). For example, employees with firm-specific knowledge (i.e., knowledge-based employees who are considered both valuable and unique to the organization) will have different needs than job-based employees (i.e., those who are important to the organization but comparatively easy to replace). The term "HR architecture" has been used to refer to the differentiated system of HR practices addressing both the needs of various constituents within the organization and the conringencies posed by the organization's strategy and environment.

Thus, the particular treatment of retirement within an organization depends on the organization's business strategy, its particular environmental constraints and contingencies, and the types of jobs or employment arrangements within the 
organization. While various typologies of business strategy have been proposed, the following distinetions suggested by Porter (1985) are useful for considering human resource pracrices: cost leadership (competing by providing low-cost product or services), innovation/differentiation (finding ways to set one's products or services apart from competitors), and quality enhancement (competing by providing high-quality goods and services).

Schuler and Jackson (1987) discussed the various behaviors that employees would need to exhibit to support three different business strategies. For example, to support an innovation/differentiation strategy, employees would need to exhibit high levds of creativity, a long-term focus, a high degree of cooperative and interdependent behaviors, a greater willingness to take risk, and high tolerance for ambiguity and unpredictability. By contrast, to support a cost leadership strategy, employees would need to demonstrate predictable and repetitive behaviors, a shorter-term focus, primarily autonomous behaviors, and low risk-taking. Finally, to support a quality enhancement strategy, employees would have to exhibit a longer-term focus, high concern for precision and quality, high concern for processes, low risk-taking, and a high degree of commitment to the organization's goals.

Given these distinctions, a different atritude toward employee retirement could be expected by virtue of the organization's strategy and supporting culture of human resources management. Under an innovation/differentiation strategy, the organization may wish to design a retirement plan that will hold the employee to the organization for longer periods of time but also take advantage of their relative willingness to take risks. Under a cost leadership stratgy, the organization's culture of stability and low risk-taking might best be supported by a retirement plan that minimizes risk while encouraging an earlier retirement date. Meanwhile, to support quality enhancement, the employer might want to design a benefit plan that minimizes risk while tying the individual to the organization.

The work of the National Council on Compensation Insurance (NCCI), a south Florida-based nonprofit organization, illustrates the value of tailoring a retirement plan to the organization's strategy (Nichols, 2008). In designing its retirement benefits, $\mathrm{NCCl}$ first determined its business mission and values and used these to state a philosophy (or objecrives) for its retirement plan. $\mathrm{NCCl}$ determined that its business strategy required "retention of knowledgeable, long-service employees" and should provide adequate means for employees to retire (Nichols, 2008). After conducting a systematic analysis of options, $\mathrm{NCCl}$ decided to make several changes to their retirement plans, including implementation of automaric enrollment and increases to a $401(\mathrm{k})$, an improved vesting schedule, the addition of a Roth 401 ( $k$ ), implementation of formal retirement education for its employees, and the adoption of a phased retirement option (Nichols, 2008).

This example illustrates one aspect of strategic planning for retirement-matching the business strategy to the specific type of retirement plan. However, organizations must engage in a good deal more than that if they are to be adequately prepared for the effects of retirement. They must also be able to adequately manage their workforce through human resources forecasting and succession planning. Next, we will discuss how organizations plan strategically for retirement through aggregate planning (i.e., looking at the workforce flow as a whole in the organization) and individual succession planning (i.e., looking at how organizations plan for changes in key individual positions).

\section{Methods of Strategic Management Workforce Management (HR Planning)}

A significant component of HR strategy is a dear understanding of the organization's workforce transitions: entry into the organization, movement through the organization, and exiting the organization. HR planning is a term used to describe the process of forecasting and planning for these workforce transitions using a variety of qualitative and quantitative forecasting techniques aimed at predicting an organization's labor supply and demand. It is designed to project the nature and type of jobs that will be needed in the organization, as well as the knowledge, skills, and abilities that will be needed to meet the organization's needs in the future.

HR planning is very proactive in nature. The attempt to specify labor needs three to five years into the future allows organizations to take long-term steps to address anticipated shortfalls or excesses. For example, a sheer-metal manufacturer may project a significant shortfall of skilled welders due to retirements in the next five years. Looking at the labor market and the projected graduation rates of welders from two-year technical colleges, they may also project a shortage of qualified welders in the labor market. This foreknowledge allows them time to establish relationships with area high schools, develop student internships, and/or establish scholarships, all of which would help to increase 
the supply of welders (and interest in the company as a potential employer) before the projected wave of retirements.

HR planning involves six steps: (1) assessing strategic initiatives and context, (2) forecasting labor demand, (3) forecasting internal and external labor supply, (4) reconciling supply and demand, (5) developing an action plan, and (6) evaluating success. In the first step of strategic planning, the organization needs to assess its strategic initiatives for the next three to five years and conduct a thorough evaluation of the context within which it operates. This will include a review of product or service demands, technological changes, availability of financial resources, absentecism and turnover trends, projected organizational growth or decline, current productivity levels, and anticipated changes in economic or competitive positioning. This evaluation will help to establish any changes the organization needs to be prepared for in the nexr three to five years. For example, if the organization anticipares purchasing new technology that will increase worker productivity by $15 \%$, then they may need to prepare to downsize the workforce over the same period.

Once the key changes in the environment are identified, the organization can use either qualitative or quantitative methods to forecast labor demand. Qualitative methods include bottom-up estimates (managerial estimates of the number of employees they will both need and have available to them over the designated time period) and top-down estimates (estimates by top-level management as to the number of employees they are willing to employ). Quantitative estimates include using trend analysis (using past employment trends to project furure trends), productivity ratios (using historical ratios between jobs to forecast changes in one job relative to another), and multiple regression to forecast demand using several factors known to predict employment levels within the organization.

There are two primary methods of forecasting labor supply within the organization: skills inventory analysis and Markov analysis. Skills inventory analysis involves tracking (using a human resource information system) the various skills of individuals within the organization. Reports can then be generated to evaluate and estimate the skills that will be available over time, Markov analysis focuses on forecasting movements between jobs within the organization. It uses the organization's past history of job movement (promotion, demotion, lateral moves, and exits) to estimate the probability of various movements between jobs. These probabilities are then applied to the existing workforce and used to predict labor supply in various positions. Among other things, Markov analysis is useful for anticipating the time employees spend at various positions and levels within an organization (Heneman \& Sandver, 1977) and hence can be used to predict both career "slowdown" as one nears retirement and organizational exits due to retirements.

Putting the forecasted demand and forecasted internal supply together, the organization will determine whether there is a predicted shortage or surplus of labor over the next three to five years. A forecasted shortage means the organization will need to hire additional employees, while a surplus may indicate the need for downsizing. Once these needs are determined, an action plan can be developed.

Clearly the implications for retirement are very different in each condition. Shortages will tend to encourage the organization to find ways to retain qualified employees longer (i.e., focus on retention). An organization might, for example, offer older workers an incentive to stay beyond an anticipared retirement age. They may offer flexible work schedules, temporary assignments, consulting contracts, or part-time options such as job-sharing to make working more attractive to older employees (Society for Human Resource Management/American Associations for Retired Persons, 1998). They might also develop bridge employment options (e.g., allowing the individual to take a position with less responsibility or perhaps make a career change). Finally, they might refocus recruitment efforts to bring former retired employees back to the organization or conduct targeted recruitment aimed at attracting retirees back into the workforce.

On the orher hand, organizations in retrenchment often focus on employees close to retirement as a way to downsize. An organization may allow vacancies generated through the normal course of retirements to remain unfilled (downsizing through attrition). It may also attempt to generate more vacancies by offering early retirement incentives to encourage voluntary turnover among older workers. Here, too, the organization may consider asking older workers to move to part-time schedules or to rake lower-level positions as other vacancies arise (and as a way to reduce compensation levels).

Thus, in either the case of shortage or surplus, employees nearing retirement play a key role in strategic staffing management. The fact that older employees' career trajectories are more predictable than those of younger workers and that some of 
them may be more open to the possibility of reduced hours or organizational exit makes them an ideal demographic for managing fluctuations in staffing needs. Of course, these strategies often have a cost associated with them. In the case of early retirement programs, for example, the organization will need to wrestle with the effects of knowledge transfer and loss as older, experienced workers retire. We will explore these issues in greater detail below.

\section{Succession Planning}

Whereas HR planning is used to forecast an organization's overall labor (and skill) supply and demand, succession planning is used to project staffing changes for an individual position. Succession planning is used primarily for positions, such as key managerial jobs, where it is necessary or desirable to immediately fill a position should it become vacant or where substantial training (both general and firm-specific) may be needed to effectively do the job. Succession planning is both an HR planning tool that allows an organization to maintain smooth transitions and a career planning tool that allows it to identify potential talent and provide the training and experience employees need to progress within the organization. The need for succession planning is increasingly recognized by organizations. According to one study conducted for the Society for Human Resource Management, about $58 \%$ of responding companies indicated that their organization had some type of succession planning in place, and about one-quarter had plans to implement succession planning (Fegley, 2006).

Succession planning is generally accomplished by creating a "replacement chart" for key positions. For a given position, the chart indicates which of the current employees are potentially qualified to move into the position and how many years before they would be considered ready to assume the responsibilities. The chart is generally accompanied by an analysis of each potential replacement's knowledge and experience gaps. This allows the organization to (1) identify potential talent, (2) identify any urgent needs for developing a successor pool, and (3) better plan for addressing any gaps that may exist. Organizations vary in the degree of formality used in administering their succession plans. Some use purely subjective assessments of talent, while others send employees to formal assessment centers to identify strengths and weaknesses. Some have formal career development programs that help employees address their knowledge and skill gaps, while others leave employees to figure our how to do this on their own. More formal programs are generally less subject to problems of favoritism, personal biases, and unequal opportunities for women and minorities.

While historically succession planning has been used for a small subset of key employees, organizations are expanding its use. Some organizations use succession planning throughout their organizations in planning for management and other professional or key technical positions (Rothwell, 2010). Rothwell (2010) described the trend away from succession planning for the purpose of managing promotion to one that meets the need for knowledge transfer. To manage knowledge transfer, organizations are increasingly relying upon retirees, a fact that can and should be planned for in the process of succession planning. Rothwell (2010) referred to this as "technical succession planning" and noted that the key difference is that the focus is on "transferring knowledge from those who possess special knowledge, gained for experience within the organization (institutional memory) and experience doing the work (tacit knowledge)" (p. 52). Such a process requires management commitment, clarification of work processes and technical competencies, a knowledge inventory (identifying who within the organization possesses particular types of knowledge), identification of who is at risk of loss due to retirement, formulation of a plan to address the gap, implementation of the plan, and evaluation of the plan's success (Rothwell, 2010).

Despite the number of companies either implementing or planning to implement succession planning, there is clearly room for improvement. According to Barnett and Davis (2008), most organizational leaders do not feel confident that their succession planning processes will be effective in helping to address impending HR needs such as skills shortages. Further, they argued that data on managerial and CEO performance suggests that many managers (and CEOs) are likely to fail in their positions, suggesting that succession planning is not as effective as it should be. They also argue that this is due in part to poor design and methodology, particularly because the organization focuses too much on specific positions and not more broadly on the organization's talent needs.

These criticisms highlight the need to tie succession planning to the overall staffing plan developed through the staffing planning process as well as the organization's business strategy. Succession planning in an organization that is pursuing a strategy of excellent quality of product or service may find that 
internal promotion paths that allow for cross-functional experiences and training allow individuals to see the product or service from a variety of perspectives, which, in rurn, generates improved quality. As individuals near retirement, they will have gained a variety of experiences that can also make them valuable "rehires" following retirement because they can be placed in many different positions. On the orher hand, a company that is focusing on cost containment may conduct succession planning using clear internal promorion paths through one functional arca so as to gain efficiencies associated with deep knowledge of a particular area. The narrower job paths and deep knowledge may indicate a need for stronger mentoring and knowledge transfer proto$\mathrm{col}$ as these employees near retirement. Succession planning with an eye toward strategy can help the organization to manage career paths more effectively for both the business and its employees. In turn, it is argued that succession planning can aid HR in developing its strategic partnership with the top management tcam (Barnett \& Davis, 2008; Ulrich \& Bearty, 2001) as HR begins to demonstrate its ability to fill strategic staffing needs.

\section{Issues for a Pre-Retirement Workforce}

From an individual standpoint, retirement is a process that begins long before, and continues well after, one retires. This "temporal view" (Shultz \& Wang, in press) of the retirement process is also shared by employers. The key task in the years leading up to the point when a worker officially retires is retirement preparation. Retirement preparation involves planning and taking those actions needed before retirement to help ensure that one has a satisfying lifestyle after retirement. The main way in which organizations help workers with their retirement preparation is through the provision of employee benefirs. Although organizations do offer benefits to meet goals for corporate social responsibility, they also offer benefits to attract and retain workers, increase productivity, and foster positive work-related attitudes among employees. As such, employee benefits are an important part of the HR architecture. Employee benefits are expensive for employers. Indeed, employers spend about 30\% of their total compensation budgets on employee benefits (BLS, 2010a). This amounts to some 1.5 trillion dollars that is spent annually on employee benefits (EBRI, 2008). Because they are so expensive, it should come as no surprise that organizations must be concerned about costs and cost containment as they develop and administer the types of benefit programs that will help them meet their strategic goals.

\section{Pre-retirement Financial Preparation}

One of the most important aspects of retirement preparation is in the area of finances. That is, preparing to replace the stream of income during the time one is retired that had formerly come from work. Traditionally, retirement income has come from three main sources: social security programs, employer-provided retirement benefit programs, and personal savings. Employer-provided retirement income benefit programs have been the main way in which organizations have helped employees fund their retirement years. Retirement income bencfit programs are fairly common in the United States, with $71 \%$ of private-sector workers having access to such programs and $80 \%$ of those having access actually raking part (BLS, 2009a). While there are a variery of specific rypes of retirement income benefit programs, they are generally divided into two broad categories: (1) defined bencfir (DB) plans and (2) defined contribution (DC) plans. Each of these two types of programs has features to consider in the context of an organization's strategy.

As the name implies, DB plans specify a particular benefit payout level (typically in the form of lifetime installments) once the employee retires. The payout level is determined by a formula, which most commonly includes the employee's length of service and earning history with the employer. Employees must work for a specified period of rime before becoming eligible (vested) for a payout at retirement. Typically, this vesting period is five years. DB plans are not portable. They cannot be transferred from onc employer to another. As a result of these rules the largest payouts accrue to those who have remained with a single employer for a long period of time and have their highest earnings with that employer. The funds used to generate the payout are not under the control of the employees, and the employees do not direct how those funds are invested. In DB plans the organization makes a long-term cost commitment and assumes the market risk (fluctuations in the investment markets). Thus there is considerable uncertainty for the organization. The employee assumes the "service" risk. That is, that they will continue working for the same employer over a long period of time. It is also the case that these plans "penalize" work with that same employer beyond a certain point. This is because the additional benefit amount provided for additional years of work rarely approaches the amount of benefit lost by forfeiting 
a year of payout. This feature makes it easier to predice when people will retire.

In DC plans the amount of payout upon retirement is not specified, but an amount of investment contribution is. That is, the employer agrees to contribute a certain amount (usually a percent of salary) to a retirement investment account such as a 401 (k) or 403(b) account. Oftentimes, both the organization and employee make contributions. The payout at retirement is based on how well the investment account has performed. DC plans are "owned" by the employee, and the employee directs how the contributions are invested across a set of funds (e.g., mutual funds). DC plans are portable. If employees leave an organization they may transfer their account into other retirement accounts. In this type of plan the organization has much greater certaincy surrounding the costs of the plan. The amount of contribution is generally known from year to year. Because they are portable, employees do not assume the service risk; however, because they are employee-directed, employees assume the market risk.

At one time DB plans were the more common of the two types of plans. However, over the past twenty years there has been a considerable shift from DB to DC plans, and currently more private-sector workers are covered by DC $(56 \%)$ than DB plans $(31 \%)$ (BLS, 2009a). Research suggests that this shift has been driven by several factors, including (1) regulatory changes that make defined benefit plans more difficult and costly to administer; (2) the shift from traditional manufacturing, unionized industries to service (nonunionized) industries, and with it the disappearance of union contracts; and (3) the changing nature of the workforce itself (e.g., increased number of women, dual career couples, education levels, etc.), which has made for an increasingly mobile workforce that needs retirement plans that can "move" with them (e.g., Aaronson \& Coronado, 2005; Broadbent, Palumbo, \& Woodman, 2006).

In their discussion of pension plans, Westerman and Sundali (2005) use psychological contract theory (Rousseau, 1989, 1995) to describe how the shift from DB to DC plans affects the relationship between the employees and their employers. The term psychological contract refers to an employee's perception of the implicit exchange relationship, or set of mutual obligations, between employee and employer. They can range from being highly relational to highly transactional. Highly relational psychological contracts are based on mutual trust and loyalty and tend to be more long term. Highly transactional psychological contracts are based on the economic exchange of employee effort for employer-provided inducements. They argue that DB plans tend to signal relational psychological contracts between employee and employer whereas, DC plans tend to signal transactional psychological contracts between employee and employer. They also suggest that the shift from DB to DC plans is just one part of a broader movement toward more transactional employment relationships generally. Considering these factors, the shift from DB to DC plans at the aggregate level can be viewed as organizations responding in a strategic manner to align their retirement income benefit offerings to the realities of their production processes and labor markets under a given set of constraints (government regulations and costs).

At the level of the individual organization, these same factors call for designing a retirement income benefit plan that is aligned with the overall strategy of the organization (internal alignment) and the characteristics of labor market (external alignment). Some organizational strategies, such as those that seek to gain competitive advantage through employees who must acquire and use organizational-specific knowledge or customer relationships developed over a long period of time, can be enhanced by benefit strategies that promote long-term relationships berween employer and employees. Some organizational strategies can benefit from the predictable exit of employees owing to those workers' preferences or concerns about productivity at older ages (c.g., as might be seen in physically demanding manual labor positions). These types of strategies likely benefit from some of the features of DB plans. On the other hand, some organizational strategies, such as those that seek to leverage technological and other types of innovation among employees, may find that long-term employment relationships do not enhance the organization's ability to compete, nor are they necessarily preferred by a labor market that has grown increasingly concerned with mobility. In these types of scenarios, organizations are likely to benefit from the features of DC plans.

In addition to offering retirement income benefits, organizations can also help employees meet retirement income needs by encouraging full participarion in those benefit programs as well as by encouraging increased personal savings for retirement. Research data consistently show that many people are woefully unprepared for retirement, and this is especially true in the area of financial 
preparation (Adams \& Rau, in press; Munnell, Webb, \& Golub-Sass, 2009; Purcell, 2009a). People optimize neither their participation in plans that are offered through their employer nor their personal savings outside of the workplace. Some of the main reasons for this lack of preparation include a lack of basic financial literacy needed to develop a sound financial plan (Hershey, Mowen, \& Jacobs-Lawson, 2003; Hershey, Walsh, Brougham, Carter, \& Farrell, 1998; Lusardi \& Mitchell, 2007) and the "willpower" needed to implement it (Benartzi \& Thaler, 2007). Organizations have begun to address this issue in rwo ways. The first is by reducing the effort the employee needs to exert to participate in employer-provided retirement income benefit programs such as defined contribution plans. This is accomplished, for example, through automatic enrollments in the plan and escalations that increase the contribution level of the employee over time. Since passage of the Pension Protection Act of 2006, which encouraged automatic enrollments, the number of organizations offering this feature has increased to $19 \%$ (BLS, 2010b), with larger organizations more likely to offer it. The research evidence to date would suggest that automatic enrollment increases participation rates in $401(\mathrm{k})$-type pension plans (GAO, 2009).

The second way organizations can try to address the issues that prevent employees from optimizing their participation in DC plans, and that may extend into their personal savings outside of the workplace, is by offering financial education and planning benefits to employees. One recent survey found that financial education was provided by $75 \%$ of large firms and $51 \%$ of small firms and, of those offering financial cducation, $43 \%$ reported providing education focused on retirement and $33 \%$ reported providing financial education on topics other than retirement (Miller, 2009). Research on the efficacy of financial education programs suggests that they can produce positive changes in financial knowledge (Hershey et al., 1998), savings behavior (Clark, d'Ambrose, McDermed, \& Sawant, 2006; Hershey, Mowen, \& Jacobs-Lawson, 2003), and participation in voluntary savings plans (Bayer, Bernheim, \& Scholz, 2009). Some evidence also suggests that the most effective way to deliver these types of programs is frequently offered retirement seminars as opposed to written materials (Bayer, Bernheim, \& Scholz, 2009).

Both automatic enrollment/escalation and educational programs can have a positive effect on employees' financial preparation for retirement.
However, neither come without costs and other consequences, and a firm's decision about offering them should be a strategic one. This fact was highlighted by several examples given in the GAO report that reviewed auromatic enrollment/escalation programs (GAO, 2009). For instance, the GAO report described an employer in a low-wage, high-turnover environment that would tend to incur all of the administrative costs of automatic enrollments for employees who would accumulate only small balances that would likely be taken as lump-sum payouts. Thus, the costs would have been incurred without achieving any of the desired outcomes of the program. It may also be the case in low-wage high-turnover environments that employees would be sensitive to the likelihood of low balances and perceive an automatic contribution as a reduction in salary as opposed to an actual benefit. This may make it more difficult to recruit workers. With regard to offering financial education seminars, there may be situations where they are simply cost prohibitive. This could occur when an organtzation has adopted a focused low-cost strategy and profit margins are narrow, thus making it difficult to reflect the additional costs of the financial education seminars in the price of its goods and services.

\section{Other Retirement-Related Benefits}

In addition to retirement income, an organization can offer many orher benefits aimed at protecting employees after they retire. These include retiree health benefits, health savings accounts, and long-term care insurance. Retiree health benefits are health insurance programs that cover workers after they retire. Approximately $23 \%$ of private-sector workers over the age of 65 have access to such programs (BLS, 2009b). Changes in government regulations and the downturn in the economy have led some employers to stop offering these benefits or reduce coverage. Unlike some other benefits, unless the organization has made specific promises or surrendered the right to change their plans, these plans can be eliminated or changed by organization. Health savings accounts allow employees and their organizations to contribute to an account to be used to pay the cost of qualified medical expenses if employees are covered by high-deductable health insurance plans. These accounts can be used for retiree health expenses (for those with high-deductible health plans and not enrolled in Medicare) because the balance of the account can be carried forward from year to year and they are portable (the employee retains the account if he or she leaves the employer or the 
workforce). Approximately 15\% of private-sector employees have access to health savings accounts (BLS, 2010c). Long-term care insurance is meant to cover the costs associated with nursing home and certain in-home care. Approximately 16\% of private-sector workers have access to this type of insurance.

Like all benefit decisions, the decision by an employer to offer any of these types of benefits, and the manner in which they are offered, should be based on a number of factors. At the most basic level, employers provide benefits to align employee behaviors and attitudes with organizational strategy before they retire and to provide employees with some security after they retire, while being mindful of costs. However, these three goals do not always coincide with one another. For example, in the ease of retiree health benefirs, an organization may want to foster long-term relationships with employes by demonstrating legitimate concerns for their long-term welfare. Retiree health benefits would seem one mechanism to accomplish this. However, they are costly, and the research suggests that older employees are as much as $21 \%$ more likely to leave their current employer if they have access to retiree health benefits (Robinson \& Clark, 2010). Thus, rather than encouraging longer tenure, this benefit might be used to encourage employees to retire if its costs can be justified for that purpose. In this case, the organization might be better off considering other benefits that signal organizational support. This example illustrates the need for careful consideration of the utility of each benefit within the package, as well as the way they will interact in affecting employee attitudes and behaviors.

\section{Issues for a Retiring Workforce}

As we have just argued, helping employees plan for retirement in a way that is both consistent wirh, and supportive of, organizational strategy is an important function of human resource management. However, HR is also faced with several strategic decisions regarding the management of a "retirement-ready" or aging workforce. The Bureau of Labor Statistics estimated that the number of workers aged 65 and older increased by $101 \%$ between 1977 and 2007 and further projects that between 2006 and 2016 the number of workers aged 65 to 74 will increase an additional $36.5 \%$ (BLS, 2008). These numbers have significant implications regarding the management of employees who are close to retirement. We address two key issues here: knowledge rransfer, and the motivation and performance of a retirement-ready workforce.

\section{Knowledge Transfer}

One area of particular concern for organizations is the loss of accumulated knowledge that can occur when employees retire (DeLong, 2004). In one recent survey, $71 \%$ of employers reported being concerned about the loss of knowledge resulting from the retirement of older employees (MetLife, 2009). Although the sum amount and value of lost knowledge are difficult to quantify, anecdotal evidence suggests that they are considerable. Delong (2008) gives the example of the loss of engineering knowledge critical to maintaining an organization's production process. Another example would be the loss of knowledge regarding customer preferences and idiosyncrasies necessary to make sales. Knowledge itself can be described along a number of dimensions. It can range from explicit, relatively easily expressed knowledge to tacit knowledge that is known by an individual but difficult to express (Polanyi, 1966). Knowledge can also come in several forms ranging from intellectual knowledge focused on information, facts, and concepts to social knowledge focused on interpersonal relationships and access to social networks (Peterson \& Spiker, 2005; Nahapiet \& Ghoshal, 1998). In order to retain the accumulated knowledge of its reriring employces, organizations need a knowledge management process that is able to identify and transfer valuable knowledge so that it can be used by others to achieve organizational objectives (Argote \& Ingram, 2000; Nonaka \& Takeauchi, 1995; Slagter, 2007; Wang \& Noc, 2010).

The HR manager plays a key role in the knowledge management process. To begin, the HR manager must work with senior managers to determine the size and scope of the knowledge management effort based on an assessment of the organizarion's strategy, resources, and knowledge base as well as employee demographics and capabilities. These will allow the organization to develop the knowledge management approach most suited to its needs. An important part of this process is being able to locate and identify the rype and value of the knowledge to be retained. Once this process is underway, the organization can begin developing the knowledge transfer process.

Key elemenrs of the knowledge transfer process aimed at retiring workers include facilitating an organizational culture that supports knowledge transfer and developing and deploying specific tools 
needed to achieve knowledge transfer. Important clements of a culture that supports knowledge transfer include (1) valuing employees nearing retirement for what they know, (2) creating mutual respect and trust among the parties to the process, and (3) emphasizing learning and development (Slagter, 2007). Human resources management practices such as reward and recognition programs can facilitate the development of such a culture. The importance of these cultural elements are supported by recent research in the general knowledge management literature linking knowledge management practices to organizational performance (Zack, McKeen, \& Singh, 2009). They are especially important in the context of knowledge transfer from retiring employees given that, in most cases, the retiring employee is leaving the organization and transferring their knowledge to a younger generation (Calo, 2008; Stevens, 2010).

In terms of developing and deploying specific knowledge transfer tools, the organization has a wide range of options. Although there are a number of ways to conceptualize them (e.g., Nonaka \& Takeauchi, 1995), specific knowledge transfer tools can be seen as falling into two broad overlapping categories: (1) documenting processes and (2) interpersonal processes. Documenting processes focus on knowledge transfer in written (most often in electronic) form to create repositories of knowledge. The tools used to create these involve task-based and cognitive job analysis methods, the development of procedure manuals, expert-system and knowledge-base support tools, and training programs. Interpersonal processes focus on knowledge transfer via interactions with those who have the knowledge. Traditional tools for accomplishing this include succession planning, structured on-the-job training and apprentice programs, job shadowing and developmental job assignments, and coaching/ mentoring. Other methods include critical incident and after-action review sessions, communities of practice, story-telling sessions, and internal help desk and consulting teams.

The rools and approaches to knowledge transfer for any particular organization necessarily involve a consideration of all of the issues described above. They must match tools and approaches to strategy and types of knowledge. They must also consider the learning preferences of the knowledge transfer parties (older and younger workers) and tailor their methods accordingly (Piktialis \& Greenes, 2008). For instance, we are aware of a large manufacturer of automobile parts with a low-cost strategy achieved through routinization and standardized processes that faced a substantial loss of senior workers through retirement. Although there was a large quantity of knowledge to transfer, much of it was relatively easy to articulate. In this instance, documenting approaches combined with formal and on-the-job training worked well. This organization also recognized differences across the retiring and replacement workforce in terms of age and language (incoming workers were younger and often spoke Spanish as their primary language) and used a technology application with embedded video that included some Spanish language segments. This type of approach would likely not work well in an organization with an innovation/differentiation strategy that needed to transfer a greater amount of tacit knowledge from retiring workers to younger workers. In this instance the organization might consider the more interpersonal knowledge transfer approaches. It would also be important to establish a culture that encourages and values knowledge-seeking on the part of the younger workers and knowledge-sharing on the part of the retiring workers.

\section{Motivation and Performance Management}

Anorher significant challenge for managing a workforce close to retirement is maintaining motivation and work performance. While there is little empirical evidence to suggest that motivation (Forteza \& Prieto, 1994; McEvoy \& Cascio, 1989; Rhodes, 1983) and performance necessarily decline with age (e.g., McEvoy \& Cascio, 1989; $\mathrm{Ng} \&$ Feldman, 2010; Waldman \& Avolio, 1986), there is growing evidence that there is something unique about motivating older workers. Techniques that work on younger workers may not be effective on older workers nearing retirement.

To determine an appropriate strategic response, it is important to consider motivation as it pertains to older workers. While there is not a lot of research on this issuc, several theories have been proposed. Kanfer and Ackerman (2004) argued that process-oriented theories of work motivation, such as expecrancy theory or goal theory, cannot completely explain differences in work motivation by age. These theories, according to Kanfer and Ackerman (2004), operate in much the same way as for younger workers. Instead, the differences in motivation between younger and older workers can be explained by age-related changes in competencies and motives, including what is needed to protect self-concept. 
Research shows that fluid intellectual abilities (Gf) such as abstract reasoning and attention decline as we age. By contrast, crystallized intellectual abilities $(\mathrm{Gc})$ such as experiential knowledge, extent of vocabulary, and verbal comprehension continue to increase even after middle age (Schaie, 1996). Using Kanfer's (1987) model of expectancy theory, Kanfer and Ackerman (2004) proposed that the change in intellectual abilities affects motivation primarily through the effort-performance link. In particular, older workers will begin to lose motivation and interest for high-Gf jobs (e.g., line work, air traffic controller, and engineering) because greater effort is necessary to attain the same level of performance (or, in some cases, performance cannot be maintained even with greater effort). Workers in high-Gf jobs are likely to demonstrate greater interest in jobs that demand high levels of Gc (e.g., supervisory work, teaching). Thus, those who are already in high-Gc jobs are more likely to sustain motivation throughout their careers. This conclusion would appear to be supported by research on career development (Maurer, 2001) that suggests that older workers avoid development opportunities that might put them in a bad light (c,g., technology training) while being drawn to those opportunities that they are more confident they can master (e.g., soft skills training). It is also supported by work by de Lange, Van Yperen, Van der Heijden, and Bal (2010) that concluded that, relative to younger workers, older workers were more likely to indicate their goals were ones of mastery-avoidance (i.c., goals that focused on maintaining performance, memory, skills, and abilities).

Warr $(1997,2001)$ also suggested that expectancy theory may be useful to understand older workers' motivation but focused primarily on the fact that older workers are motivated by different job characteristics. Older workers' preferences are more likely to include things like security (physical, job, financial) and opportunitics to utilize their skills rather than high job demands, job variery, and feedback. Thus, as workers age, organizations may find that they are not motivated by the same things as in the past. This suggests that, as an organization's workforce ages, the reward structure may need to be realigned with worker needs and desires.

Claes and Heymans (2008) conducted focus group sessions with HR managers and identified three motivation theories that might be useful in explaining the work motivation of older workers. First, cognitive evaluation theory (Deci \& Ryan, 1991) suggests that feelings of autonomy, self-efficacy, and relatedness with others influence motivation. HR managers interviewed by Claes and Heymans indicated that older workers attached more importance to having contact with their superiors, a relationship with the owner, and opportunities to take on responsibility and consequently were more motivated when these conditions were mer. Second, consistent with Locke and Latham's (1990) goal setting theory, interviews with HR managers suggested that older workers were more motivated when they were given clear goals that were challenging and time-related. Third, the HR managers observed that older workers were highly motivated by the opportunities to mentor others, pass along their knowledge, and gain recognition for their efforts.

Kooij, de Lange, Jansen, and Dikkers (2008) conducted a literature review of age and work motivation using five different conceptualizations of age: chronological, functional, psychosocial, organizational, and life span (de Lange et al., 2006). They concluded that where organizations (or countries) use chronological age as a marker (e.g., to define a "normal" retirement age, offer age-related benefits, or establish a mandatory retirement age), workers are more likely to experience lower job involvement, feelings of work as a burden, and feelings of reduced comperence. Further, these organizations are less likely to invest in training and development for older workers. Chronological age is therefore argued to have a negative effect on the motivation of older workers. Functional age, as determined by cognitive abilities and physical health, was argued to decrease motivation for certain occupations; for example, where Gf demands are high or where reasonable accommodations cannot be made for physical limitations. Healthier older workers are less likely to suffer from motivation declines than those experiencing cognitive or physical decline. Psychosocial age refers to the individual's self-concept as it pertains to aging as well as the social perception of age. Kooij et al. (2008) concluded that those who viewed rhemselves as "old" or who experienced social cues that indicated they were "old" (i.e., limited opportunities for training, lack of performance feedback, assumptions about retirement readiness) were less likely to sustain motivation to work. The impact of organizational age, or tenure within an organization, would seem to depend largely on the organization's policies. Kooij et al. (2008) concluded that there was insufficient evidence to determine which was more important: positive motivation effects stemming from steep 
earnings curves or negative effects stemming from career and earnings plateaus. However, there is considerable research that shows that job attitudes in general are affected by career stage, so it is likely that, regardless of organizational tenure, the stage of one's career will also have an effect on motivation (positive or negative). Finally, Kooij et al. (2008) concluded that there is not strong evidence that life span age (early, middle, and late adulthood) has an impact on motivation, although some research indicates that priorities with regard to work and leisure time shift in accordance with life span age.

It is clear that HR managerial laments about the difficulty of motivating older workers nearing retirement are well-founded. This brief summary of the age and motivation literature shows that the research indicates a complexity that is not yet well understood. To match motivation strategy with the organization's strategy, the HR manager must first understand the source of low motivation among older workers. The research summarized here suggests that it could be due to declining physical or cognitive abilities, changing preferences for work-related outcomes, negative social signals, existing organizational policies and practices, life stage pressures, and interactions between the job and the individual.

Still, we can draw some guidance for HR strategy with the understanding that the key question is whether the organization wishes to encourage older workers to retire or wishes to extend older workers' value in the workplace. As with other policies discussed earlier, a company concerned about cost containment may wish to encourage retirement of older, more expensive workers. These organizations could adopt more chronological age policies and practices that establish an implied retirement age. They may want to offer early retirement, create benefits for retired employees, or designate an age for phased retirement eligibility.

On the other hand, an organization that is focused on quality of service, product, or processes may wish to extend the work life of older, knowledgeable workers for as long as possible. HR policies and practices that accommodate older workers' changing physical and cognitive challenges (e.g., job redesign, ergonomic changes, job reassignment, and career development) should increase work motivation for older workers. Accommodating older workers' changing preferences for leisure and work may also encourage them to stay in the workplace longer, albeit with reduced hours but perhaps with sustained motivation.
While complex, the fundamental advice to HR managers is the same whether motivating younger or older workers: to effectively manage motivarion, HR managers must understand their business strategy, the current context of work (social, organizational, and demographic), its existing policies and practices, and, of course, the preferences and needs of their workforce.

\section{Issues for Organizational Interactions with Retirees}

As noted earlier, for many organizations the relationship between employer and employee does not end when the employment relationship is terminated. Given the projected skill labor shortage, many organizations are taking steps to nurture relationships with former employees and establish relationships with other retirees. In the next section, we discuss the advantages and challenges of retaining retirees and recruiting them back into the workforce.

\section{Retirement Work}

While in the past retirement may have been thought of as a one-time exit from full-time work, this is no longer the reality for a sizable portion of older workers (Adams \& Bechr, 2003). Indeed, people now engage in a wide range of post-retirement work arrangements (Giandrea, Cahill, \& Quinn, 2009; Gobeski \& Bechr, 2009; Purcell, 2009b). Much of the research in this area has focused on "bridge employment," with its connotation as a transitional period of gradually stepping down from full-time work to full-time retirement (Feldman, 1994; Shultz, 2003). Even this term, however is becoming a bit of a misnomer. Post-retirement work can take a variery of forms (Wang, Adams, Beehr, \& Shultz, 2009). It may be full-or part-time, with one's pre-retirement employer or some other (including self-employment). It may be continuous or include alternating between periods of work and non-work. It can involve the same or different types of work than one did during one's earlier career, and it may be motivated by a variety of reasons (Dendinger, Adams, \& Jacobson, 2005; Loi \& Shultz, 2007; Wang et al., 2009). Regardless of the form it may take or the reasons for it, many older workers express a desire to continue working after they have formally retired (Bond, Galinsky, Kim, \& Brownfield, 2005; Brown, 2005). This desire among older workers and current retirees to continue in paid work has the effect of expanding an employer's internal and external labor markers. 


\section{Retention}

The key HR issue for the internal labor market (an organization's current employees) is retention. Retention efforts can be aimed at retaining workers in the organization on a full-time basis (delaying retirement altogether) or part-time basis. A study conducted by Hewitt Associates found that $61 \%$ of the employers they surveyed indicated that they have or will develop programs to retain targeted employes nearing retirement (Miller, 2008). Owing to the downturn in the economy over the past several years and in response to changes in public pension (c.g., social security) policies, a large number of workers intend to continue working full-time (Agewave, 2010). Retaining employees to work on a part-rime basis involves the use of phased retirement and contingent work arrangements. Phased retirement refers to the continuing employment of current employees at a reduced workload. It does not involve a separation from the organization before commencing. Formal phased retirement programs offered to all employees tend to be relatively less common than informal programs. Studies estimate that between $6 \%$ and $22 \%$ of employing organizations use formal programs, and approximately $50 \%$ to $65 \%$ offer informal phased retirement on a case-by-case basis (Bond, Galinsky, Kim, \& Brownfield, 2005; Hutchens \& Grace-Martin, 2006; SHRM, 2008). Contingent work arrangements include approaches such as rehiring retired workers as independent contractors and as "temporary" workers through staffing organizations (Shulrz, 2001). These work arrangements do involve employees separating from the organizations before they commence.

An individual's decision to delay retirement and/or pursue post-retirement employment with one's current employer is based on a complex set of factors that include individual differences, contextual factors, and work-related variables (Adams \& Bechr, 2003; Bechr \& Bennett, 2007; Feldman, 1994). Many of the individual differences such as demographic characteristics and work-related preferences, as well as contextual factors such as the state of the larger economy, are beyond the control of any parricular organization. Work-related variables such as working conditions, pay, and benefirs are more directly influenced by the organization. These work-related variables can be used to persuade employees who would otherwise rerire to continue working for their current employer. As already discussed, workers who have greater accumulated income and have reached pension eligibility are more likely to retire. Thus, the rypes of benefit plans offered can have the effect of encouraging continued work with one's current employer.

In addition, workers with positive attitudes about work are more likely to retire later than those with negative attitudes (Adams \& Beehr, 1998; Luchak, Pohler \& Gellatly, 2008; Madvig \& Shultz, 2008; Taylor \& Shore, 1995). An organization wanting to retain older workers would need to develop HR practices and policies that contribute to such positive attitudes among older workers. For example, onc recent study found that $H R$ practices such as training and development targeting older workers were positively related to perceptions of organizational support, which was, in turn, related to intention to remain with one's employer (Armstrong-Stassen \& Ursel, 2009). Of course, organizations can also try to match working conditions to employee preferences. For instance, evidence suggests that workers prefer flexible schedules, which may lead organizations to respond by developing specific flexible work options (Matz-Costa \& Pitts-Catsouphes, 2010).

\section{Recruitment}

When considering the external labor market (those who do not work for the organization), the key issue is recruitment. Recruitment is the process of attracting potential employees to apply for open positions in an organization. In one national study of 578 organizations, approximately $62 \%$ had taken steps to recruit an age-diverse workforce (Pitts-Catsouphes, Smyer, Matz-Costa, \& Kane, 2007). Much of the research on applicant attraction suggests that it is based on objective and subjective characteristics of the job (e.g., pay, type of work, etc.) and the organization (c.g., organizational image), the applicants' perceptions of the fit between these characteristics and their own preferences, and the competence and credibility of the recruiter (Chapman, Uggerslev, Carroll, Piasentin, \& Jones, 2005; Lievens \& Highhouse, 2003).

An organization wishing to engage in the targeted recruitment of retirees can use a number of approaches to attract them. One approach would be to attempt to match the characteristics of the job and organization to those that are generally preferred by older workers. For instance, research shows that there are several main HR practices related to retirees returning to work. These include (1) Alexible work options; (2) training and development opportunities; (3) new, challenging, and meaningful work assignments; (4) improved compensation; (5) unbiased feedback and performance evaluation; and (6) recognition and respect (Armstrong-Stassen, 
2008a, 2008b; Brown, Aumann, Pitts-Catsouphes, Galinsky, \& Bond, 2010). In order to be effective in recruitment, these types of practices have to be communicated in a manner that signals to retirees that the organization values their contributions (Rau \& Adams, 2005). Of course, they also have to be communicated via appropriate channels. Organizations have a number of options for targeting retirees who may be active or passive job seekers (Adams $\&$ Rau, 2004). Among orhers, these include (1) direct mail, (2) newspapers/internet, (3) posters in places that retirees frequent, (4) radio, (5) employment agencies, (6) open houses/informational seminars, and (7) networking and referrals (Fyock, 2005).

Like the choice to engage in any other HR activities, the choice to engage in targeted efforts to retain and recruit retirees is based on the strategy of the organization. To begin, it should be recognized that retention and recruitment are only one set of options for ensuring that the work of the organization gets accomplished. There are alternatives that might better fit a particular organization (c.g., job redesign and redistribution, outsourcing, off-shoring, etc.) that can be considered. Organizations choose between retention, recruitment, or some mix of the two based on their advantages and disadvantages. Retention strategies can have the advantages of facilirating knowledge transfer, signaling a long-term commitment to employees, reducing costs for on-boarding, etc. The disadvantages of retention strategies can include a lack of new ideas and approaches, difficulty meeting affirmative action goals, blocked mobility channels for younger workers, etc. Recruitment strategies are just the opposite. They have the advantages of being able to bring in new ideas, helping to meet diversity and affirmative action goals, opening mobility channels, erc. Recruitment strategies have disadvantages in that they can be more costly to implement, they create costs for on-boarding new employees, etc.

Both retention and recruitment can be challenging to implement for organizational reasons as well as legal and regulatory reasons (Hill, 2010; Noble \& Harper, 2010). Many of the suggestions for both retention and recruiting rely on the notion of creating part-time work (reduced responsibility, fewer hours per day, fewer days per week, seasonal employment) and creating contingent work arrangements. While these are attractive to retirees, part-time work is not the most optimal configuration for all jobs. In addition, organizations might have legitimate concerns about the job performance of some of its employees. In this case, certain retirements, like other types of turnover, may be very functional. As a result, these broadly offered retiree retention programs might not make as much sense as limited and focused retention programs.

It is also true that some efforts aimed at retaining older workers can have the opposite effect. That is, rather than retaining workers who would have retired, they may encourage workers who otherwise would have continued working full-time to retire in favor of part-time work (Greller \& Stroh, 2003). Indeed, phased retirement and contingent work arrangements have been used as early retirement incentives as opposed to incentives for continued work (Feldman, 2003). There are also legal barriers to phased retirement programs (Hill, 2010; Noble \& Harper, 2010). For example, the Pension Protection Act of 2006 relaxed some restrictions on in-service distributions from defined benefit plans while continuing to work for the plan sponsor (e.g., for those 62 and older or who have reached the plan's normal retirement age; Purcell, 2009b). However, there is still lirtle guidance about how to administer these distributions, and some have raised concerns about the legality of targeting older employees for part-time work if that part-time work is at a reduced pay and benefits (Hill, 2010).

Considering the advantages, disadvantages, challenges to implementation, and costs, organizations attempt to choose the mix of retention and recruitment activities that is best aligned with their strategy. Clearly, organizations that are not experiencing or expecting to experience vacancies and those that may be in retrenchment are not likely to be interested in retention or recruitment to any great extent. Organizations adopting a cost leadership strategy with a focus on routine and standardized work processes and/or a workforce concentrated in jobs that require skills that are widely available in the labor marker can benefit from broad recruiting approaches (seek to attract large numbers of applicants). In this case, recruiting retirees may be a small part of their broader approach. An organization adopting an innovation strategy where new ideas and approaches are important might be better served by recruitment strategies than retention strategies. An organization adopting a differentiation strategy, which relies on firm-specific knowledge and relationships or requires specialized skills not generally available in the labor market, is likely to benefit from retention strategies and narrowly targeted recruitment efforts. 


\section{Conclusion}

According to the Government Accountability Office (GAO, 2005), most organizations in the United States have not yet made hiring and retaining older workers a priority. According to AARP's list of "Best Employers for Workers Over 50," some notable exceptions include Cornell University, First Horizon National Corporation, National Institutes of Health, S. C. Johnson \& Son, and Massachusetts Institute of Technology (AARP, 2010). These employers engage in a variety of practices, some of which we described in this chapter, to attract, retain, and motivate older workers. However, their practices are not identical. Rather, these organizations design recruitment, rraining and career development, workplace accommodations, alternative work options such as flexible scheduling, job sharing and phased retirement, employee health, pension, and retiree benefits that are consistent with their overall business strategy. The fact that they give such careful attention to the impact of their policies and practiees on older workers sets them apart from most other employers.

From our review of the literature, we can derive several reasons why most employers have yet to fully develop policies and practices pertaining to retirement. First, many employers have not yet felt the pinch of retirements that has been forecasted for several years. While their workforces are aging, employees are choosing to work longer for a variety of social and economic reasons. While these organizations may be feeling some of the effects, such as lower motivation, difficulties with training, and/or increased physical health problems, the effects are still relatively subtle. Until the problems become acute or there is a wave of retirements that creates a crisis of knowledge within the organization, other issues are likely to continue to take priority.

Second, many organizations are new to the concept of strategic HR planning. As such, HR continues to strive to be perceived as a strategic business partner that can add value to an organization. As HR departments increase in sophistication and become strategic business partners, we would expect them to expand their strategic planning efforts and hence become more aware of, and prepared for, issues related to management of an older and retiring workforce.

Third, given the complexity of the issues regarding retircment, organizations may simply be confused as to how to manage the problems they are experiencing. Motivation is a good case in point. While managers struggle with how to motivate older workers or those nearing retirement, they often continue to rely on the same methods of motivation that worked when these individuals were younger. They may, for example, offer carrots in the form of higher pay or sticks in the form of disciplinary action. However, as we have seen, older workers' values, needs, and expectations are different from younger workers', and these tools are not likely to be effective. Hence, what is required is for HR to step back from what has worked in the past, educate themselves on the unique features of an older workforce, and evaluate their current policies and practices against what is needed to support the business strategy.

Fourth, employers cite several barriers to offering more opportunities to older workers. According to the GAO's study (GAO, 2005), these barriers include federal pension regulations prohibiting the distribution of DB pension benefits while an employee is still employed with the organization, older workers' resistance to change and/or new technology, difficulties in rehiring retired workers who are trying to maintain income levels that would still allow them to collect their Social Security and/ or Medicare benefits, and societal norms that condition workers to expect retirement by age 65 (or younger).

Finally, we cannot ignore the fact that older workers are still subjected to stereotyping and discrimination. In their review of the age discrimination literature, Wood, Wilkinson, and Harcourt (2008) noted that older workers are underrepresented in the labor market, find it more difficult to re-enter the workforce once they have left it, take significantly longer to find alternative employment, and are less likely to secure a job interview than younger workers. Older workers are stercotyped as being less flexible, resistant to change, less willing to accept new technology, less alert, less reliable (due to health issues), less "trainable," and less productive (Wood et al., 2008). Further, studies on older workers in many countries find that high numbers of them perceive that they are discriminated against (e.g., McMullin \& Marshall, 2001; Ginn \& Arber, 1996).

This list illustrates the challenges associated with bringing retirement into the strategic planning process. To help organizations prepare for the workforce of the future, researchers and educators must work to raise awareness, encourage strategic planning, bring the existing research to bear on older worker issues, and resolve some of the unanswered questions affecting the intersection of $\mathrm{HR}$ and older 
workers. As to this latter point, we offer several suggestions for future research.

\section{Future Directions}

To improve the degree to which organizations engage in strategic planning, it would be helpful to identify more clearly (and empirically) the advantages to organizations of engaging in HR planning and succession planning. Research that can establish the extent to which HR planning and succession planning improve HR's strategic value to the organizarion, as proposed by Ulrich and Beatty (2001), would help to lend these practices credibility and much-needed top management support. In addition, we know that HR planning and succession planning processes can be improved. Research aimed at helping organizations do a better job of both will address the lack of confidence many managers feel with their current planning practices (Barnett \& Davis, 2008).

Given the lack of preparedness for retirement by so many workers, there is a great need for research addressing the psychology behind retirement planning and preparation. Adams and Rau (in press) called for additional research exploring why certain demographic groups plan better than others, the role of personality traits in financial planning, and/ or psychological barriers to financial planning. This work would allow HR managers to design policies that help to prepare their workforce and/or design interventions (e.g., training) aimed at encouraging financial preparedness.

In the area of motivation, there is a need for more research addressing the relationship between age and motivarion, a meta-analysis to estimate age-related effects and identify moderating variables, and, perhaps most importantly, conceptual work that can offer a comprehensive theoretical framework that can incorporate the various perspectives presented/ offered by researchers.

In this chapter, we have attempted to highlight some of the key strategic HR decisions that bring the worlds of strategic HR and psychology together. We would be remiss, however, if we failed to mention that there are many other decisions made by organizations regarding the management of older and retirement-age workers that we did not address presently. Each functional area of HR must be considered. In addirion to staffing planning, recruitment, benefits, and motivation/performance management, organizations must design training and development programs, compensation structures, employee relations programs, and occupational safety and health programs that meet the needs of an aging workforce. It should be clear by now that the needs of an aging workforce will need to permeate the very culture of the organization.

This cannot be achieved without careful strategic planning. Faced with an aging workforce, most organizations will need to examine their HR policies and practices to ensure that the treatment of older workers is both ethical and legal. But beyond the demands of ethics and legal compliance, anticipated skilled labor shortages mean that organizations need to think more strategically about how they are utilizing the potential of their older workforce. For some organizations, it may mean a focus on retention and seeking labor in unusual places (c.g., among the retired population). For others it may mean retrenchment and downsizing in ways that allow the organization to maintain its knowledge base and manage its key resources more effectively. Today's organizations must resist the temptation to follow the crowd and instead think strategically abour which policies and practices make the most sense in their unique competitive situation. In any case, it is clear that HR policies related to retirement will play a key role in meeting the business needs of the future.

\section{References}

Aaronson, S., \& Coronado, J. (2005). Are firms or workers behind the shift away from $D B$ pension plan? Board of Governors of the Federal Reserve System (U.S.). Finance and Economic Discussion Series, Washington, DC: Federal Reserve Board.

AARP. (2010), AARP best employern for workers over 50. Washington, DC: Author. Rerrieved from http://www. aarp.org/work/employec-benefits/info-09-2009/BestEmployers_Winners_2009.html.

Adams, G. A., \& Beehr, T. A. (1998). Turnover and retirement: A comparison of their similarities and differences. Persomnd Bychology 51, 643-665.

Adams, G. A., \& Bechr, T. A. (2003). Retirement: Reasons, proreors, and nesults. New York, NY: Springer.

Adams, G., \& Rau, B, L. (2004). Job seeking among retirees sccking bridge employment. Penonnd Bycholoxy. 573). $719-744$.

Adams, G. A., \& Rau, B. (2011). Purting off tomorrow to do what you want today: Planning for retirement. Amerinan Bychologist. 66, 180-192.

Agewave. (2010). Retirement at the tipping point: The year that changed everyshing. Conducted by Harris Interactive. Recrieved from hrtp://wwwagewave.com/RetirementTippingPoint.pdf

Argote, L., \& Ingram, P. (2000). Knowledge transfer: A basis for competitive advantage in firms. Organizational Bedravior of Human Decision Procresses. 82(1), 150-169.

Armstrong-Stassen. M. (2008a). Organisational practices and the post-retirement employment experience of oldes workers. Humian Resource Mantgement Journal, 18(1), 36-53. 
Armstrong-Stassen, M. (2008b). Human resource practices for mature workers - and why aren't employers using them? Asia Pacific Journal of Human Resources, 46(3). 334-352.

Armstrong-Stassen, M., \& Ursel, N. (2009). Perceived organizational support, career satisfaction, and the retention of older workers. Journal of Occupational ơ Organizational Pychology. $82(1), 201-220$.

Bamett, R, \& Davis, S. (2008). Creating greater success in succession planning. Aduatuces in Developing Human Resources, JO(5), 721-739.

Bayer, P., Bernheim, B., \& Scholz, J. (2009). The effects of financial education in the workplace: Evidence from a survey of employers. Economic Inquiry, 47(4), 605-624.

Becker, B. E., \& Huselid, M. A. (1998), High performance work systems and firm performance: A synthesis of research and managerial implications. Research in Personnel and Human Resounce Management, 16, 53-101.

Becker, B. E., \& Husclid, M. A. (1999). Strategic human resource management in five leading firms. Human Resource Management, 38, 287-301.

Beehr, T. A., \& Bennett, M. M. (2007). Examining retirement from a mulri-level perspective. In K. S. Shulrz \& G. A. Adams (Eds.), Aging and work in the 21st century (pp. 277-302). Mahwah, N]: Lawrence Erlbaum.

Benartzi, S., \& Thater, R. (2007). Heuristics and biases in retirement savings behavior. Journal of Economic Perspectives, 2I(3), 81-104.

Bond, J. T., Galinsky, E., Kim, S. S., \& Brownficld, E. (2005). National study of employers. New York, NY: Families and Work Institute.

Boxall, P., \& Purcell, J. (2008). Strategy and human resource management (2nd ed.). Basingsoke, UK: Palgrave Macmillan.

Broadbent, J., Palumbo, M., \& Woodman, E. (2006). The shift from defined benefit to defined contribution pension plansImplicarions for asser allocation and risk matnagement. Report prepared for a Working Group on Institutional Investors. Global Savings and Asset Allocation established by the Committee on the Global Financial System. Retrieved from http://www.bis.org/publ/wgpapers/cgfs27broadbent3. pdf.

Brown, K. S. (2005). Arritudes of indiriduats 50 and older toward phased retirement. Washington, DC: AARP Knowledge Management.

Brown, M. Aumann, K., Pitt-Catsouphes, M. Galinsky, E., \& Bond, J. (2010, July). Working in retirement: A 2lst century phenomenon. Farnilies and Work Institute. Retrieved from http://familiesandwork.org/site/research/reports/workinginretirement.pdf.

Bureau of Labor Staristics. (2008), Spotlight on older workers. Retrieved from http://www.bls.gov/spotight/2008/older workers/.

Bureau of Labor Statistics. (2009a, March). Retirement benefits: Access, parricipation, and take up rates data table. Employee Benefits Survey. Retricved from http://www.bls.gov/ncs/ebs/ benefies/2009/ownership/civilian/table02a.htm

Bureau of Labor Statistics. (2009b, March). Health-related benefits: Access data table. Employee Benefits Survey. Retrieved from http://www.bls.gov/nes/ebs/benefits/2009/ownership/ civilian/table 39a.hum.

Bureau of Labor Statistics. (2010a, June 9). Employer costs for employee compensation news release text. Economic News Release. Retrieved from http://www.bls.gov/news.release/ ccec.nr0.htm.
Bureau of Labor Statistics. (2010b. August 30). Disparities in automatic enrollment plan availability. Compensation and Working Conditions. Retrieved from http://www.bls.gov/ opub/cwc/cm20100824ar01p1.htm.

Bureau of Labor Staristics. (2010c, June 9). Financial benefits: Access data table. Employee Benefits Survey. Retrieved from http://www.bls.gov/ncs/ebs/benefits/2010/ownership/civilian/ table25a.htm.

Calo, T. (2008). Talent management in the era of the aging workforce: The critical role of knowledge transfer. Public Personnel Management, 37(4), 403.

Chapman, D., Uggerslev, K., Carroll, S., Piasentin, K., \& Jones, D. (2005). Applicant attraction to organizations and job choice: A meta-analytic review of the correlates of recruiting ourcomes. Journal of Applied Psychology, 90(5), 928-944.

Claes, R., \& Heymans, M. (2008). HR professionals' views on work motivation and retention of older workers: A focus group study. The Career Development International, 13(2), 95-111.

Clark, R., d'Ambrose, M., McDermed, A., \& Sawant, K. (2006). Retirement plans and savings decisions: The role of information and education. PEF 5(1), 45-67.

de Lange, A. H., Taris, T. W., Jansen, P. G. W., Smulders, P., Houtman, I. L. D., \& Kompier, M. A. J. (2006). Age as a factor in the relation between work and mental health: Results from the longitudinal TAS study. In J. Houdmont \& S. Mclntyre (Eds.), Occupational bealth psychology: European perspectives on research, education and practice (Vol. 1. pp. $21-45$ ). Maia, Portugal: ISMAI.

de Lange, A. H., Van Yperen, N., Van der Heijden, B., \& Bal, P. (2010). Dominant achievement goals of older workers and their relationship with motivation-related outcomes. Journal of Vocational Behatior, 77(1), 118-125.

Deci, E., \& Ryan, R. (1991). A motivational approach to self: Integration in personality. Nebraska Symposium on Motivation, 1990: Perspectives on motivation (pp. 237-288). Lincoln, NE: University of Nebraska Press.

DeLong, D. (2004). Lost knowledge: Confronting the threat of an aging uorkforce. New York, NY: Oxford University Press.

Delong, D. (2008). Five keys to decisions vis-a-vis an ageing workforce. Inside Knowledge, 11(5). Retrieved from http://www.ikmagazine.com/xq/asp/txtSearch.DELONG/ exactphrase.1/sid.9B1CAF41-CD0A-4B5D-B1684480F17D502B/articleid.01D4A543-A588429C-BB1F-0DFF2693120C/qx/display.htm.

Dendinger, V.. Adams, G., \& Jacobson, J. (2005). Reasons for working and their relationship to retirement attitudes, job satisfaction and occupational self-efficacy of bridge employces. The International Journal of Aging of Human Development, $6 I(1), 21-35$.

EBRI: Employee Benefit Research Institute. (2008). Retirement annuity and employment-based pension income among individuals age 50 and over. Notes, $29(11), 2$.

Fegley, S. (2006). 2006 succession planning survey report. Alexandria, VA: The Society for Human Resource Management.

Feldman, D. (2003). Endgame: The design and implementation of early retirement incentive programs. In G. A. Adams \& T. A. Bechr (Eds.), Retirement: Reasons, processes, and results (pp. 115-135). New York, NY: Springer.

Feldman, D. C. (1994). The decision to retire early: A review and conceptualization. Academy of Management Revieu, 19, 285-311. 
Forteza, J. A., \& Pricto, J. M. (1994). Aging and work behavior. In H. C. Triandis, M. D. Dunnette, \& L. M. Hough (Eds.) Handbook of industrial and organizational pindology (2nd ed., Vol. 4, pp. 446-483). Palo Alto, CA: Consulting Psychologist Press.

Fyock, C. (2005, December), Strategies for recruiting workersover 50. Society for Humatn Resource Management. Retrieved from http://www.shrm.org/hrdisciplines/staffingmanagement/ Articles/Pages/CMS_014873.aspx.

Government Accountability Office. (2005). Older workers labor can belp employers and employees plan better for the future (GAO-06-80), Washingron, DC: Author.

Giandrea, M., Cahill, K., \& Quinn, J. (2009). Bridge jobs: A comparison across cohorts. Research on Aging, 31(5), 549-576.

Ginn, J.. Arber, S. (1996) Gender, age and attitudes to retirement in mid-life. Ageing and Sockety, 16, 27-55.

Gobeski, K., \& Bechr, T. (2009). How retirees work: Predictors of different types of bridge employment. Journal of Orgunizational Behatior, 30(3), 401-425.

Government Accounting Office. (2009). Automatic enrollment shous promise for some workers, but proposals to broaden retirement savings for other workers could face challenges. Washington, DC: Author.

Greller, M., \& Stroh. L. (2003). Extending work lives: Are current approaches tools or talismans? In G. A. Adams \& T. A. Bechr (Eds.), Retirement: Reasons, processes, and rosults (pp. 115-135). New York, NY: Springer.

Heneman, H. G., III, \& Sandver. M. G. (1977). Markov analysis in human resource administration: Applications and limitations. Academy of Management Revieus 2(4), 535-542.

Hershey, D., Mowen, J., \& Jacobs-Lawson, J. (2003). An experimental comparison of retirement planning intervention seminars. Educutional Gerontology, 29(4), 339-359.

Hershey, D., Walsh, D., Brougham, R., Carter, S., \& Farrell, A. (1998), Challenges of training pre-retirees to make sound financial planning decisions. Educational Gerontology. 24(5), 447.

Hill, I. M. (2010). Why doesn't every employer have a phased retirement program? Benefits Quarterly, Fourth Quarter, 29-39.

Huselid, M. A. (1995). The impact of human resource management practices on turnover, productivity, and corporate financial performance. Academy of Management Journal, 38 , 635-672.

Hurchens, R., \& Grace-Martin, K. (2006). Employer willingness to permit phased retirement: Why are some more willing than others? Industrial \& Labor Relations Review. 59(4). 525-546.

Kanfer, R. (1987). Task-specific motivation: An integrative approach to issues of measurement, mechanisms, processes, and determinants. Journal of Social and Clinical Bychology. 5, 237-264.

Kanfer, R., \& Ackerman, P. L. (2004). Aging, adult development, and work motivation, Academy of Management Review, 29(3), 440-458.

Kooij, D., de Lange, A., Jansen, P., \& Dikkers, J. (2008). Older workers motivation to continue to work: Five meanings of age. Journal of Managerial Pychology, 23(4), 364-394.

Lepak, D., \& Snell, S. (2002). Examining the human resource architecture: The relationships among buman capital, employment, and human resource configurations. Journal of Mamagement, 28, 517-543.
Lievens, F., \& Highhouse, S. (2003). The telation of instrumen. tal and symbolic attributes to a company's attractiveness as an employer. Personnel Byschology, 56(1), 75-102.

Locke, E., \& Latham, G. (1990). Work motivation: The high performance cycle. In U. Kleinbeck, - H. Quast, H. Thierry, $\&$ H. Hacker (Eds.), Work motitation (pp. 3-25). Hillsdalc, NJ: Lawrence Erlbaum.

Loi, J., \& Shultz, K. (2007). Why older adults seek employment: Differing motivations among subgroups. Journal of Applied Gerontology, 26(3), 274-289.

Luchak, A., Pohler, D., \& Gellarly, I. (2008). When do conmitted employees retire? The effects of organizational commitment on retirement plans under a defined-benefit pension plan. Human Resource Management, 47(3), 581-599.

Lusardi, A., \& Mirchell, O. (2007). Financial literacy and retirement preparedness: Evidence and implications for financial education. Business Economics, 42(1), 35.

Madvig. T., \& Shultz, K. (2008). Modeling individuals post-retirement behaviors toward their former organization. Journal of Workplace Behuvional Health, 23(1/2), 17-49.

Matz-Costa, C., \& Pitt-Catsouphes, M. (2010). Workplace flexibility as an organizational response to the aging of the workforce: A comparison of nonprofit and for-profit organizations. Joumal of Social Service Rescanch, 36(1), 68-80.

Maurer, T. J. (2001). Career-relevant learning and development, worker age, and beliefs about self-efficacy for development. Journal of Management, 27, 123-140.

McEvoy, G. M., \& Cascio, W. R. (1989) Cumulative evidence on the relationship between employee age and job performance. Journal of Applied Bychology, 7\$(1), 11-17.

McMullin, J. A., \& Marshall, V. W. (2001). Ageism, age relations and garment industry work in Montreal. The Gerontologitr, $41(1), 111-122$.

Metlife. (2009, December). The emerging retirement model study. New York, NY: Metropolitan Life Insurance Company.

Miller, S. (2008, August 8). Retiring boomers prompt increase in phased retirement. Saciety for Human Resource Matnagement. Retrieved from htrp:/www.shrm.org/hrdisciplines/ benefits/ Articles/Pages/RetiringBoomersPromptPhasedRetirement. aspx.

Miller, S. (2009, November 4). SHRM poll looks at financial education in the workplace. Society for Human Resource Management. Retrieved from http://www.shrm.org/hrdisciplines/benefits/Articles/Pages/FinancialEducationPoll.aspx.

Munncll, A., Webb, A., \& Golub-Sass, F. (2009)). The national rerirement risk index: After the crash. Center for Retirement Research at Boston College, Issue Bricf 9-22.

Nahapiet, J., \& Ghoshal, S. (1998). Social Capiral, intellectual capital, and the organizational advantage. Academy of Management Review, 23(2), 242-266.

Ng, T., \& Feldman, D. (2010). The relationships of age with job attitudes: A meta-analysis. Personnel Byshology, 63(3). $677-718$.

Nichols, G. A. (2008), Reviewing and redesigning retirement plans. Compensation ó Benefirs Revieus, 40, 40-47.

Noble, F. R. \& Harper, E. (2010). Strategy and policy for phased retirement. Bencfits Quarterly. Third Quarter, 11-14.

Nonaka, L, \& Takeuchi, H. (1995). The knowledge creating company. New York, NY: Oxford University Press.

Office of Personnel Management. (2008). An analysis of foderal employee retirement data: Predicting future retirements and examining factors releusut to retiring from the federil service. Washington, DC. Author. 
Reterson, S., \& Spiker, B. (2005), Establishing the positive contributory value of older workers: A positive psyctwology perspective. Organizational Dymamicr, 34(2), 153-167.

Pfeffer. J. (1994). Competitive advantage through people. California Management Review, 36(2), 9-28.

Piktialis, D. \& Greenes, K. (2008). Bridging the gaps: How to transfer knowledge in today's multigenerational workplace (Report No. 1428-08-RR). New York, NY: The Conference Board.

Firt-Catsouphes, M., Smyer, M., Matz-Costa. C.. \& Kane, K. (2007. July). The national study report: Phase II of the national study of business straregy and workforce development. The Center an Aging of Work/Workplace Flexibility. Retrieved from hutp://agingandwork.be.edu/documents/ RH04_NationalStudy_03-07_002.pdf.

Polanyi, M. (1966). The tacit dimension, London, England: Routledge \& Kegan Paul.

Porter, M. E. (1985). Competitive stnategy. New York, NY: The Free Press.

Purcell. P. (2009a). Retircment savings and household wealsh, in 2007 (Congressiomal Research Service No. 7-5700). Washington, DC: Congressional Research Service.

Purcell, P. (2009b), Older workers: Employment and retirement trends. Journal of Pension Planning of Complaance, 36(2), $70-88$.

Rau, B, \& Adams, G. (2005). Artracring retires to apply: Desired organizational characteristics of bridge employment. Journal of Organizational Behavior, 26(6), 649-660.

Rhodes, S. R. (1983), Age-related differences in work artitudes and behaviour: A review and conceprual analysis, Bychological Bulletin, 93(2), 328-367.

Robinson, C., \& Clark, R. (2010). Retiree health insurance and disengagement from a carcer job. Journul of Labor Reseurch, 3I(3), 247-262.

Rothwell. W. J. (2010). The furure of succession planning. Truining o Dexclopment, 6i(9), 51-54.

Rousseau, D. M. (1989) Psychological and implied contracts in organizations. Employec Rights and Responsibilities Journal, 2, 121-139.

Rouscau, D. M. (1995). Promices in action: Bychological contratss in organizations, Newbury Park, CA: Sage.

Schaic, K. W. (1996), Intellectual development in adulthood: The Seattle Longitudinal Srudy. New York, NY: Cambridge University Press.

Schuler, R. S., \& Jackson. S. E. (1987). Linking competitive strategies with human resource management practices. The Arudemy of Management Executive, 1(3), 207-219.

SHRM. (2008). Employee benefits survey. Sociery for Human Resource Mandgement. Alexandria, VA: Author.

Shultz, K. (2001). The new contingent workforce: Examining the bridge employment options of mature workers. Insernational Journal of Onganization Theary of Belhavion, $1(3 / 4), 247$.

Shulrz, K. S. (2003). Bridge employment: Work after retirement. In G. A. Adams \& T. A. Beehr (Eds.). Retinement: Reusons, proacses, and results (pp. 215-241). New York, NY: Springer.
Shulrz K. S., \& Wang, M. (2011), Psychological perspectives on the changing nature of retirement. American Bychologist, 66. 170-179.

Slagrer, F. (2007). Knowledge management among the older workforce. Journal of Knowiedge Management, 11(4), 82-96.

Sociery for Human Resource Management/AARP. (1998). Older worken surveg. Alexandria, VA: Author.

Stevens, R. (2010). Managing human capital: How to use knowledge management to transfer knowledge in today's multigenerational workforce. Internutional Business Research, 3(3), 77-83.

Taylor, M. An \& Shore, L. M. (1995). Predictors of planned retirement age: An application of Bechr's model, Pyshology and Aging, 50, 76-83.

Tsui, A., Pearce, J., Porter, L., \& Tripoli, A. (1997). Alternarive approaches to the employec organizarion relationship: Does investment in employees pay off? Academy of Management Journal, 40, 1089-1121.

Ulrich, D., \& Beatty, R. (2001), From partners to players: Extending the HR playing ficld. Human Resource Manutgement, 40, 293-308.

Waldman, D. A., \& Avolio, B. J. (1986), A meta-analysis of age difference in job performance. Journal of Applied Bycbology. 71. 33-38.

Wang, M., Adams, G. A., Beeht, T. A., \& Shulz, K. S. (2009) Bridge cmployment and retirement: Issues and opportunities during the latter part of one's career. In G. S. Baugh \& S. E. Sullivan (Eds.), Maintaining focus, energy, and options over the career (pp. 135-162), Charlotre, NC: Information Age.

Wang, S., \& Noc, R. (2010), Knowledge sharing: A review and directions for future research. Human Resource Management Review, 20(2), 115-131.

Warr P. (1997). Age, work, and mental health. In K. W. Schaic \& C. Schooler (Eds.). The impuat of work on older adults (pp. 252-296). New York, NY: Springer.

Warr, P. (2001). Age and work behaviour: Physical arributes, cognitive abilities, knowledge, personality traits, and motives. International Review of Industrial and Organizational Bychology. 16, 1-36.

Westerman, J., \& Sundali, J. (2005). The ransformation of employec pensions in the United States: Through the looking glass of organizational behavior. Journal of Orgunizarional Behruior, 26(1), 99-103.

Wood. S. (1999). Human resource management and performance. International Journal of Management Revieus, I. $367-413$.

Wood, G., Wilkinson, A., \& Harcourt, M. (2008). Age discrimination and working life: perspectives and contestations-a review of the contemporary literature, International Journal of Manugement Reviews, 10(4), 425-442.

Zack, M., McKeen, J., \& Singh, S. (2009). Knowledge managemene and organizational performance: An exploratory analysis. Journal of Knowledge Management, 13(6). $392-409$. 